\title{
Correction to: Consultation on kidney stones, Copenhagen 2019: lithotripsy in percutaneous nephrolithotomy
}

\author{
Tomas Andri Axelsson ${ }^{1}$. Cecilia Cracco ${ }^{2}$ - Mahesh Desai ${ }^{3}$ Mudhar Nazar Hasan ${ }^{1} \cdot$ Thomas Knoll $^{4}$. \\ Emanuele Montanari ${ }^{5}$. Daniel Pérez-Fentes ${ }^{6} \cdot$ Michael Straub $^{7} \cdot$ Kay Thomas $^{8} \cdot$ James C. Williams Jr. $^{9}$. \\ Marianne Brehmer ${ }^{1}$. Palle J. S. Osther ${ }^{10}$
}

Published online: 30 December 2020

(c) The Author(s) 2020

\section{Correction to: World Journal of Urology https://doi.org/10.1007/s00345-020-03383-w}

In the original publication of the article, we inadvertently left the author Kay Thomas of the submission. She has contributed to the manuscript all the way. Hence, the correct author group should be as given below:

Tomas Andri Axelsson ${ }^{1} \cdot$ Cecilia $\mathrm{Cracco}^{2} \cdot$ Mahesh Desai $^{3}$ - Mudhar Nazar Hasan ${ }^{1}$. Thomas Knoll ${ }^{4}$.. Emanuele Montanari $^{5} \cdot$ Daniel Perez-Fentes $^{6} \cdot$ Michael Straub $^{7} \cdot$ Kay Thomas $^{8}$. James C. Williams Jr. ${ }^{9} \cdot$. Marianne Brehmer ${ }^{1}$. Palle J. S. Osther ${ }^{10}$

As a result, Authors' contributions and Conflict of interest should be as given below:

Authors' contributions TAA: Analysis of data and manuscript writing. CC, MD, TK, EM, DP-F, MS: Data collection and analysis, presentation, editing of manuscript. MH: analysis of data and editing of manuscript. KT, JCW, Jr.:

The original article can be found online at https://doi.org/10.1007/ s00345-020-03383-w.

Palle J. S. Osther

palle.osther@gmail.com

1 Division of Urology, Department of Clinical Sciences, Danderyd Hospital, Karolinska Institute, Solna, Sweden

2 Department of Urology, Cottolengo Hospital of Torino, Turin, Italy

3 Muljibhai Patel Urological Hospital, Nadiad, Gujarat, India

4 Department of Urology, Klinikum Sindelfingen-Boeblingen, University of Tübingen, Sindelfingen, Germany

5 Urological Dept. at Fondazione Ca Granda-Ospedale Maggiore Policlinico of Milan, University of Milan, Milan, Italy analysis of data and editing of manuscript. MB: coordinator of project, analysis of data, presentation, writing and editing of manuscript. PJSO: coordinator of project, analysis of data, presentation, writing and editing of manuscript.

Conflict of interest TA Axelson, M Desai, MN Hasan, E Montanari, D Pérez-Fentes, M Brehmer, K Thomas, JC Williams Jr.: no conflicts of interest. C Cracco: tutor of courses for Boston Scientific; T Knoll: consultant for Storz Medical, Dornier, Olympus, and Boston Scientific; M Straub: consultant for Richard Wolf Endoscopes, Coloplast-Porgès, and Ambu; PJS Osther: consultant for Boston Scientific, Olympus, Coloplast and Bonvisi AB. None of the authors were paid to participate in the Consultation. Travel and accommodation expenses were paid by the organizers of Consultation on Kidney Stones (Lillebaelt Hospital, University Hospital of Southern Denmark and Danderyd University Hospital, Karolinska Institute).

The original article has been corrected.

6 Department of Urology, University Hospital of Santiago de Compostela, Santiago de Compostela, Spain

7 Department of Urology, University Hospital Klinikum rechts der Isar, Technical University Munich, Munich, Germany

8 Stone Unit, Guy's and St Thomas' NHS Foundation Trust, London, UK

9 Department of Anatomy, Cell Biology and Physiology, Indiana University School of Medicine, Indianapolis, IN, USA

10 Urological Research Center, Department of Urology, Lillebaelt Hospital, University of Southern Denmark, Vejle, Denmark 
Open Access This article is licensed under a Creative Commons Attribution 4.0 International License, which permits use, sharing, adaptation, distribution and reproduction in any medium or format, as long as you give appropriate credit to the original author(s) and the source, provide a link to the Creative Commons licence, and indicate if changes were made. The images or other third party material in this article are included in the article's Creative Commons licence, unless indicated otherwise in a credit line to the material. If material is not included in the article's Creative Commons licence and your intended use is not permitted by statutory regulation or exceeds the permitted use, you will need to obtain permission directly from the copyright holder. To view a copy of this licence, visit http://creativecommons.org/licenses/by/4.0/.

Publisher's Note Springer Nature remains neutral with regard to jurisdictional claims in published maps and institutional affiliations. 